\title{
Bone mineral density and markers of bone turnover in patients with renal transplantation and regular hemodialysis
}

\author{
Samir M. Ibrahim,. Khalid H Abdel-Mageed, Magdi M El-Sharkawy \\ And Abdul-Zaher M. Khattab \\ Lecturer of Internal Medicine, Ain-Shams University, Cairo, \\ "Lecturer of Pathology, Zagazig University, Zagazig,
}

\begin{abstract}
:
Background: Decreased bone mineral density (BMD) is a known complication for the uremic state antedating dialysis / renal transplantation (RTx). The issue of stabilized versus continued decrease of BMD especially on long-term basis, continues to be unresolved. Patients and Methods: In this study 20 patients on regular hemodialysis (HD-group) and 18 patients with successful first RTx (RTx-group) had been evaluated for metabolic bone changes by calcium homeostasis parameters (serum calcium, phosphorus, alkaline phosphatase "ALP" and vitamin D "calcitriol"), markers of bone formation (bone alkaline phosphatase "BAP", osteocalcin "OC", N-terminal propeptide of collagen type I "PINP"), bone resorption markers (pyridoline "PYL" and deoxypyridoline "DPYL"), and intact parathyroid hormone (iPTH). Also, BMD had been assessed by dual energy x-ray absorptiometry (DEXA) twice, at inclusion time and 3 years later. Results: comparing both groups regarding calcium homeostasis, markers of bone turnover and iPTH showed non significant difference. However, there was a significant drop of BMD (as evidenced by T-score) at follow up in the HD group, compared to stabilization of T-score for the RTx-group. Furthermore, annual T-score change was significantly more in HD-group, compared to RTx-group. Results also showed that, the best marker correlating with T-score annual changes and $\mathrm{PTTH}$ to be PINP. Irrespective of normal calcium homeostasis parameters, low BMD is a prevalent disorder among patients on regular HD and renal transplants.Conclusion: Follow up for 3 years showed stabilization of BMD for those patients with renal transplants, contrary to continued bone loss in patients on regular HD. This could raise recommendation for calcium and calcitriol supplementation, especially in the predialysis period, early post transplantation period, and continued guided replacement for those on maintenance HD. Serum PINP showed best correlations with BMD changes and iPTH and could be considered a reliable marker reflecting bone formation in those patients.

Keywords: hemodialysis, renal transplantation, markers of bone formation; bone alkaline phosphatase (BAP), osteocalcin (OC), N-terminal propeptide of collagen type I (PINP), markers of bone resorption; pyridoline (PYL), deoxypyridoline (DPYL), intact parathyroid hormone (iPTH), dual energy x-ray absorptiometry (DEXA), bone mineral density (BMD).
\end{abstract}

\section{Introduction and aim af aork:}

Chronic renal failure (CRF) is a known cause of reduction of bone mineral density (BMD) with subsequent enhanced bone fragility. The pathophysiological causes include hyperparathyroidism, parathormone resistance of bone cells, vitamin D metabolic disorders, immobility of patients, hypogonadism, amyloidosis and toxic osteodystrophy by aluminum or poor dialysis quality ${ }^{1}$. In addition, 


\section{Bone mineral density and markers}

patients with renal transplantation (RTx) have the potential negative impact of steroids and cytotoxic drugs on bone metabolism. Furthermore, increasing evidence shows that bone disease may persist or even aggravate during the first years after successful transplantation ${ }^{2}$. Trials for long-term follow up of BMD for hemodialysis (HD) and RTx patients are scarce and contradictory ${ }^{3}$. So, this trial was carried out with the following main objectives.

- Assessment and follow up of BMD changes (over 3 years) among stable patients with RTx and patients on regular HD.

- Comparison between these two groups of patients on renal replacement therapy regarding BMD changes.

- Correlating available markers of bone turnover with BMD in these patients in a trial to select the most relevant marker(s) that can reflect BMD changes.

- Elucidating any possible difference of bone turnover markers conduct between these two groups.

\section{PATIENTS:}

Thirty-eight eligible patients had been enrolled in the study after giving informed consents. Patients had been recruited from Ain-Shams University Hospitals Dialysis Units and Outpatients Nephrology Clinics during the period from 4/1999 to 9/2002. Enrollment criteria were:

- Adult male patient (to avoid the complex effect of female sex hormones, menopause, and hormone replacement therapy on bone metabolism) on thrice weekly HD or with successful first RTx for more than 2 years (to avoid the early derangement of bone metabolism by the uremic toxins) ${ }^{4}$.
- Patients would be free from other medical disorders affecting bone metabolism including thyroid dysfunctions, 1ry hyperparathyro idism, Cushing's disease, hypocalc emia / vitamin D deficiency, history of recent (within 6 months) traumatic bony fracture or evidence of a pathological fracture.

Patients had been grouped according to modality of treatment into:

1. HD-group; 20 adult male patients on regular HD. Mean age was $41.62 \pm 17.23$ years. The average dialysis period was $5.74 \pm 2.36$ years.

2. RTx-group; 18 patients with successful first RTx. Their mean age was $38.44 \pm 13.92$ years with an average transplantation period of $4.26 \pm 1.85$ years at the time of inclusion.

\section{METHODS:}

For all patients, clinical assessm ents including time of first regular dialysis / RTx, cause of renal failure and symptoms / signs representing exclusion criteria (e.g. recent fracture) were done.

Serological assessments of calci um metabolism (calcium, phospho -rus, alkaline phosphatase "ALP" and vitamin D3) were carried out by routine laboratory methods ${ }^{5}$.

Patients were also assayed for markers of bone turnover and BMD assessment by dual-energy $\mathrm{x}$-ray absorp -tiometry (DEXA) as follows:

\section{Sample collection:}

Blood sample s were collected at the same time (9AM) for all patients (before HD in HD-group). Specimens were kept on ice for 1 hour, then centrifuged at $1000 \mathrm{~g}$ for 10 minutes. Sera were stored in aliquots at $-20{ }^{\circ} \mathrm{C}$ until assayed. Frozen samples were thawed, and measurements were made 
immediately. All biochemical markers were measured in the same assay run.

\section{Markers of bone formation:}

1. Serum bone alkaline phosphatase (BAP) was measured by means of an enzyme immunoassay kit (Alkphase-B; Metra Biosystem, Mountain View, CA) ${ }^{6}$.

2. Serum osteocalcin (OC) was assayed by two-site immunora diometric assay kit (Allergo OC; Nichol's Institute, San Juan Capistrano, CA) ${ }^{7}$.

3. Serum N-terminal propeptide of type I collagen (PINP) was measu red by a competitive radioimmun oassay kit (Orion Diagnostica, Oulunsola, Finland) ${ }^{8}$.

\section{Markers of bone resorption:}

1. Serum pyridoline (PYL)

2. Serum deoxypyridoline (DPYL). These two markers were mea sured by high performance liqu id chromatography (HPLC) ${ }^{9}$.

\section{Intact parathormone (iPTH):}

This hormone was measured by immunoradiometric assay kit (Allergo iPTH; Nichol's Institute, San Juan Capistrano, CA) ${ }^{10}$.

\section{Dual-energy x-ray absorptiometry (DEXA):}

Bone mineral density had been assessed twice by DEXA scanning, once at inclusion time, and the second one 3 years later. It was done using DXA; Hologic, Waltham, MA; model QDR-2000 system. This system uses a highly collimated dichromatic x-ray source (70 KVp and $140 \mathrm{KVp})$. Bone mineral density was measured at 2 sites; lumbar spines (average of BMD at L2L4) from a lateral projection (to avoid possible descending aortic calcification effect ${ }^{11}$ ), and femoral neck. Results were expressed in calcium hydrox yapatite (gm) content divided by the projected area $\left(\mathrm{cm}^{2}\right)\left(\mathrm{gm} / \mathrm{cm}^{2}\right)$. Results were compared to the Hologic Library to express the times standard deviation (SD) change from the adult reference BMD value (T-score). Annual change of BMD had been calculated according to the following formula;

[(absolute T-score at time of inclusion) - (absolute T-score 3 years later)]/3

\section{Statistical analysis:}

Data had been statistically analyzed using PC statistical software (Statistica, Ver.5, USA). Categorical variable had been compared using a Fisher exact Chi-square test. Numerical variables had been compared by univariate analysis (two-tailed unpaired t-test for unpaired observations and two-tailed paired t-test for paired observations). Correlations had been assessed by Pearson's correlation test. $\mathrm{P}$ value $<0.05$ was used to reject the null hypothesis and identify the threshold of significance.

\section{Results:}

In this study the most common cause for ESRD was diabetic nephropathy (20\% and $16.67 \%$ for HDgroup and RTx-group, respectively), followed by obstructive uropathy and chronic pyelonephritis $(10 \%$ and $16.67 \%$ for HD-group and RTx-group, respectively), polycystic kidney disease (5\% and $11.11 \%$ for HD-group and RTx-group, respectively), hypertensive nephropathy and chronic glomerulone phritis (5\% and 5.56\% for HD-group and RTx-group, for each respectively). The cause of ESRD could not be elicited in $55 \%$ and $44.44 \%$ of cases on dialysis and transplantation, respect ively. Comparison of the distribution of causes of ESRD showed non significant difference. 
Mean values $( \pm$ SD) of calcium homeostasis parameters are presented in table (2). Values were within acceptable limits and showed non significant difference between both groups.

Regarding markers of bone turnover, values of bone formation markers in the RTx-group were higher compared to HD-group, yet this difference was statistically not significant. Comparison between both groups regarding parathormone and markers of bone resorption showed non significant difference (table 3 ).

T-scores (at entry and 3 years later) and annual $\mathrm{T}$-score changes for both HD-group and RTx-group are presented in table (4). Although Tscores were not statistically different between both groups at inclusion time and 3 years later (at both femoral neck and lumbar spine), yet annual change of T-score was statistically lower in the RTx-group $(0.013 \pm 0.067$ and $0.006 \pm$ 0.101 for femoral neck and lumbar spines change, respectively) compared to the HD-group $(-0.089 \pm 0.111$ and -
$0.050 \pm 0.032$ for femoral neck and lumbar spines change, respectively).

Comparison of the T-score at entry and 3 years later in HD-group showed significant drop for both femoral neck (from $-1.89 \pm 0.95$ to $2.19 \pm 0.090)$ and lumbar spines score (from $-2.21 \pm 0.93$ to $-2.37 \pm 0.92$ ). However, comparison of the T-score in the RTx-group, showed non significant difference (from $-1.69 \pm 1.20$ to $-1.66 \pm$ 1.14 for femoral neck, and from $-1.91 \pm$ 1.02 to $-1.89 \pm 0.89$ for lumbar spines) (table 5).

Table (6) shows correlation between annual $\mathrm{T}$-score change (reflection of BMD change) at femoral neck and lumbar spines with iPTH and markers of bone turn over in HD-group. Table (7) shows the same correlations in RTx-group. From both tables, only iPTH and PINP showed consistent significant negative correlations with annual change of T-score at femoral neck in both groups. Furthermore, together they showed significant positive correlation.

Table (1): Calcium homeostasis parameters (mean values $\pm \mathrm{SD}$ ) among the two studied groups

\begin{tabular}{|l|l|l|l|}
\hline & $\begin{array}{l}\text { HD-group } \\
\mathrm{N}=20\end{array}$ & $\begin{array}{l}\text { RTx-group } \\
\mathrm{N}=18\end{array}$ & Significance \\
\hline $\begin{array}{l}\text { S. Calcium } \\
\text { mg/dL. }\end{array}$ & $8.5 \pm 1.4$ & $8.8 \pm 0.9$ & $\mathrm{P}>0.05$ \\
\hline $\begin{array}{l}\text { S. Phosphorus } \\
\text { mg/dL. }\end{array}$ & $4.3 \pm 1.1$ & $3.8 \pm 1.4$ & $\mathrm{P}>0.05$ \\
\hline $\begin{array}{l}\text { S. Alkaline phosphatase } \\
\text { IU/L. }\end{array}$ & $108.3 \pm 13.5$ & $94.4 \pm 8.8$ & $\mathrm{P}>0.05$ \\
\hline $\begin{array}{l}\text { S. Calcitriol } \\
\text { ug/L }\end{array}$ & $19.8 \pm 5.6$ & $22.7 \pm 4.9$ & $\mathrm{P}>0.05$ \\
\hline
\end{tabular}


Table (2): Markers of bone turnover and iPTH (mean values \pm SD) in the two studied groups

\begin{tabular}{|l|l|l|l|}
\hline & $\begin{array}{l}\text { HD-group } \\
\mathrm{N}=20\end{array}$ & $\begin{array}{l}\text { RTx-group } \\
\mathrm{N}=18\end{array}$ & Significance \\
\hline $\begin{array}{l}\text { Bone alkaline phosphatase (BAP) } \\
\text { IU/L. }\end{array}$ & $27.65 \pm 9.95$ & $32.17 \pm 9.76$ & $\mathrm{P}>0.05$ \\
\hline $\begin{array}{l}\text { Osteocalcin (OC) } \\
\text { ug/L. }\end{array}$ & $164.6 \pm 78.33$ & $187.11 \pm 68.68$ & $\mathrm{P}>0.05$ \\
\hline $\begin{array}{l}\text { N-terminal propeptide } \\
\text { of type I collagen (PINP) } \\
\text { ug/L. }\end{array}$ & $58.5 \pm 35.75$ & $80.39 \pm 43.97$ & $\mathrm{P}>0.05$ \\
\hline $\begin{array}{l}\text { Pyridoline (PYL) } \\
\text { pmol/L. }\end{array}$ & $44.7 \pm 32.47$ & $43.28 \pm 29.22$ & $\mathrm{P}>0.05$ \\
\hline $\begin{array}{l}\text { Deoxypyridoline (DPYL) } \\
\text { nmol/L. }\end{array}$ & $19.5 \pm 22.51$ & $21.17 \pm 17.80$ & $\mathrm{P}>0.05$ \\
\hline $\begin{array}{l}\text { Parathyroid hormone (iPTH) } \\
\text { pmol/L. }\end{array}$ & $24.35 \pm 13.09$ & $21.11 \pm 14.03$ & $\mathrm{P}>0.05$ \\
\hline
\end{tabular}

Table (3): T-scores (at entry time and 3 years later) and annual T-score changes for patients in HD-group and RTx-group.

\begin{tabular}{|c|l|l|l|}
\hline & $\begin{array}{l}\text { HD-group } \\
\mathrm{N}=20\end{array}$ & $\begin{array}{l}\text { RTx-group } \\
\mathrm{N}=18\end{array}$ & Significance \\
\hline $\begin{array}{c}\text { T-score at entry } \\
\text { - Femoral neck }\end{array}$ & $-1.89 \pm 0.95$ & $-1.69 \pm 1.20$ & $\mathrm{P}>0.05$ \\
- Lumbar spines & $-2.21 \pm 0.93$ & $-1.91 \pm 1.02$ & $\mathrm{P}>0.05$ \\
\hline $\begin{array}{c}\text { T-score after 3 years } \\
\text { - Femoral neck }\end{array}$ & $-2.19 \pm 0.90$ & $-1.66 \pm 1.14$ & $\mathrm{P}>0.05$ \\
- Lumbar spines & $-2.37 \pm 0.92$ & $-1.89 \pm 0.89$ & $\mathrm{P}>0.05$ \\
\hline Annual T-score change & & & \\
- Femoral neck & $-0.089 \pm 0.111$ & $0.013 \pm 0.067$ & $\mathrm{P}<0.05$ \\
- Lumbar spines & $-0.050 \pm 0.032$ & $0.006 \pm 0.101$ & $\mathrm{P}<0.001$ \\
\hline
\end{tabular}

Table (4): Comparison of T-score values at inclusion and after 3 years from inclusion in each group.

\begin{tabular}{|c|l|l|l|}
\hline & T-score at entry & $\begin{array}{l}\text { T-score after 3 } \\
\text { years }\end{array}$ & Significance \\
\hline HD-group & & $-2.19 \pm 0.90$ & $\mathrm{P}<0.001$ \\
$\quad$ - Femoral neck & $-1.89 \pm 0.95$ & $-2.37 \pm 0.92$ & $\mathrm{P}<0.001$ \\
$\quad$ - Lumbar spines & $-2.21 \pm 0.93$ & & \\
\hline RTx-group & $-1.69 \pm 1.20$ & $-1.66 \pm 1.14$ & $\mathrm{P}>0.05$ \\
$\quad$ - Femoral neck & $-1.91 \pm 1.02$ & $-1.89 \pm 0.89$ & $\mathrm{P}>0.05$ \\
$\quad$ - Lumbar spines & \multicolumn{2}{|c|}{} \\
\hline
\end{tabular}




\section{Bone mineral density and markers}

Table (5): Correlation between annual T-score change at femoral neck and lumbar spines with iPTH and markers of bone turn over in HD-group

\begin{tabular}{|l|l|l|l|l|l|l|l|l|}
\hline Variable & T-neck & $\begin{array}{l}\text { T- } \\
\text { lumbar }\end{array}$ & BAP & OC & PINP & PDL & DPYL & iPTH \\
\hline T-neck & 1.00 & .31 & -.26 & $-.59^{*}$ & $-.60^{*}$ & -.38 & $-.49^{*}$ & $-.49^{*}$ \\
\hline T-lumbar & .31 & 1.00 & -.22 & -.19 & -.36 & -.12 & .12 & -.16 \\
\hline BAP & -.26 & -.22 & 1.00 & .30 & $.50^{*}$ & $.69^{*}$ & .32 & $.46^{*}$ \\
\hline OC & $-.59^{*}$ & -.19 & .30 & 1.00 & $.75^{*}$ & $.49^{*}$ & .41 & $.73^{*}$ \\
\hline PINP & $-.60^{*}$ & -.36 & $.50^{*}$ & $.75^{*}$ & 1.00 & $.66^{*}$ & $.57^{*}$ & $.81^{*}$ \\
\hline PDL & -.38 & -.12 & $.69^{*}$ & $.49^{*}$ & $.66^{*}$ & 1.00 & $.53^{*}$ & $.50^{*}$ \\
\hline DPYL & $-.49^{*}$ & .12 & .32 & .41 & $.57^{*}$ & $.53^{*}$ & 1.00 & $.54^{*}$ \\
\hline iPTH & $-.49^{*}$ & -.16 & $.46^{*}$ & $.73^{*}$ & $.81^{*}$ & $.50^{*}$ & $.54^{*}$ & 1.00 \\
\hline
\end{tabular}

T-neck $=\mathrm{T}$-score annual change at femoral neck.

T-lumbar $=\mathrm{T}$-score annual change at lumbar spines.

$*$ = Significant correlation.

Table (6): Correlation between annual T-score change at femoral neck and lumbar spines with iPTH and markers of bone turn over in RTx-group

\begin{tabular}{|l|l|l|l|l|l|l|l|l|}
\hline Variable & T-neck & $\begin{array}{l}\text { T- } \\
\text { lumbar }\end{array}$ & BAP & OC & PINP & PDL & DPYL & iPTH \\
\hline T-neck & 1.00 & $.47^{*}$ & -.34 & -.40 & $-.66^{*}$ & -.30 & -.28 & $-.76^{*}$ \\
\hline T-lumbar & $.47^{*}$ & 1.00 & -.32 & $-.49^{*}$ & $-.48^{*}$ & $-.51^{*}$ & $-.50^{*}$ & -.29 \\
\hline BAP & -.34 & -.32 & 1.00 & $.49^{*}$ & .34 & -.18 & -.07 & .12 \\
\hline OC & -.40 & $-.49^{*}$ & $.49^{*}$ & 1.00 & $.62^{*}$ & .11 & .27 & .46 \\
\hline PINP & $-.66^{*}$ & $-.48^{*}$ & .34 & $.62^{*}$ & 1.00 & $.52^{*}$ & $.49^{*}$ & $.60^{*}$ \\
\hline PDL & -.30 & $-.51^{*}$ & -.18 & .11 & $.52^{*}$ & 1.00 & .46 & .21 \\
\hline DPYL & -.28 & $-.50^{*}$ & -.07 & .27 & $.49^{*}$ & .46 & 1.00 & .17 \\
\hline iPTH & $-.76^{*}$ & -.29 & .12 & .46 & $.60^{*}$ & .21 & .17 & 1.00 \\
\hline
\end{tabular}
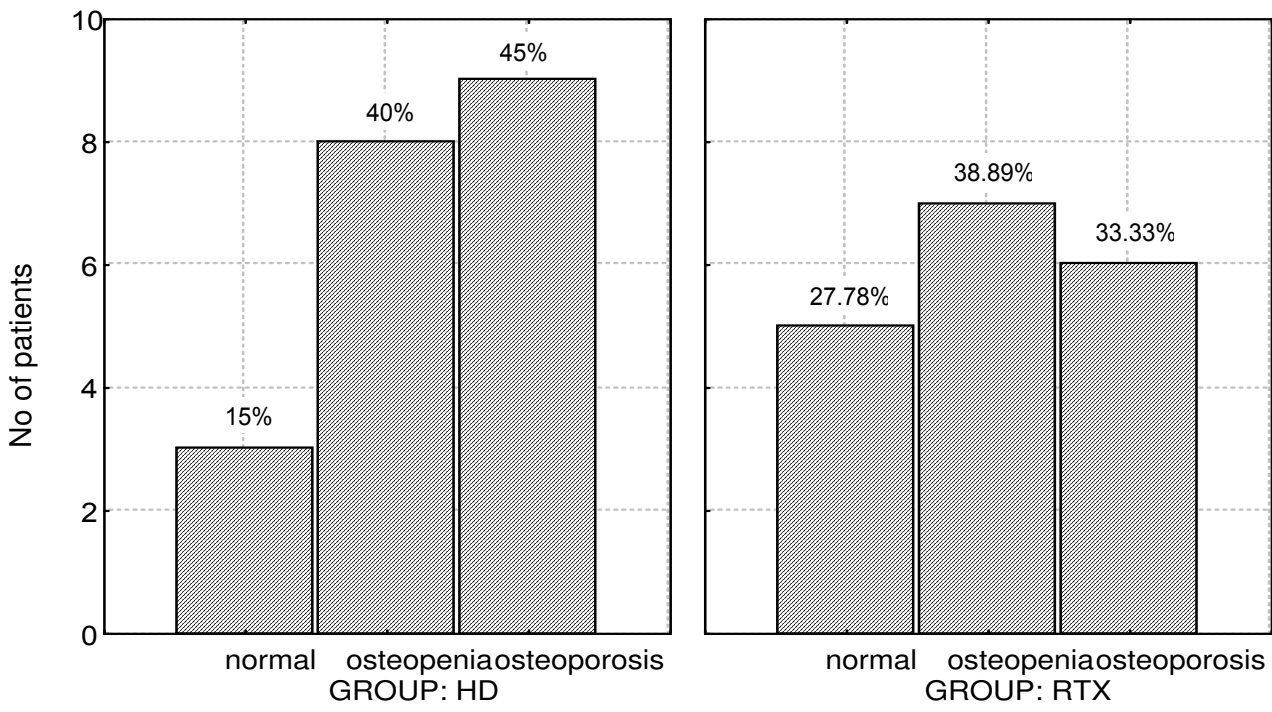

Fig. 1: Number of patients categorized by WHO criteria for $B M D(P>0.05)$ 

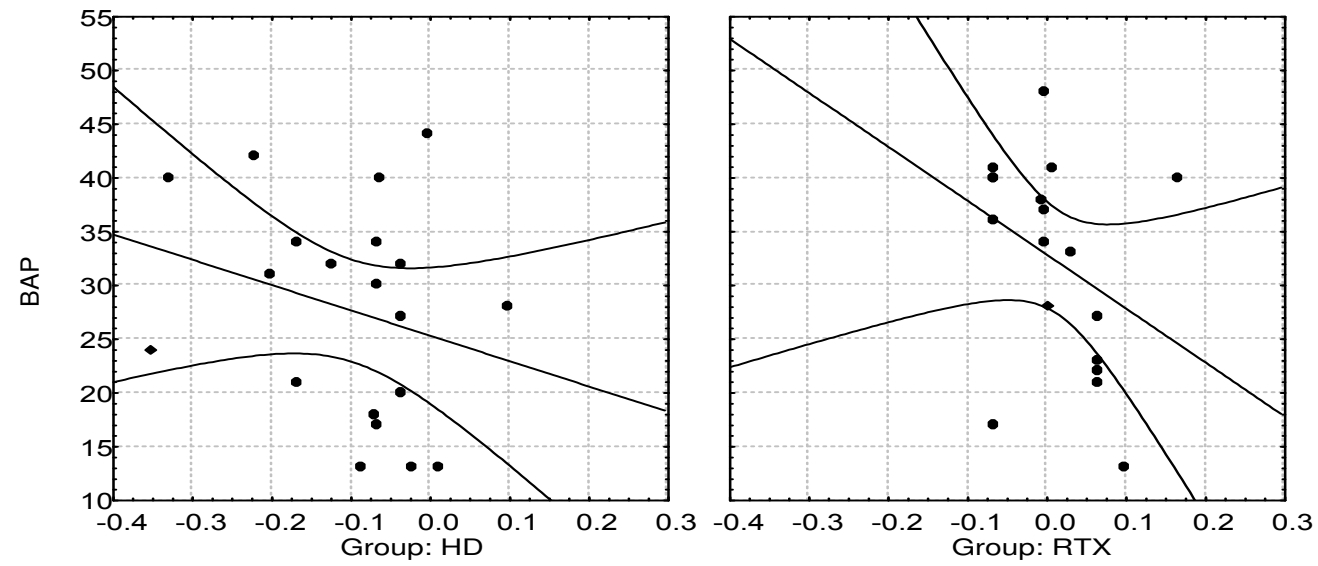

Annual T-score change at femoral neck

Fig. 2: Correlation between annual T-score change and serum BAP
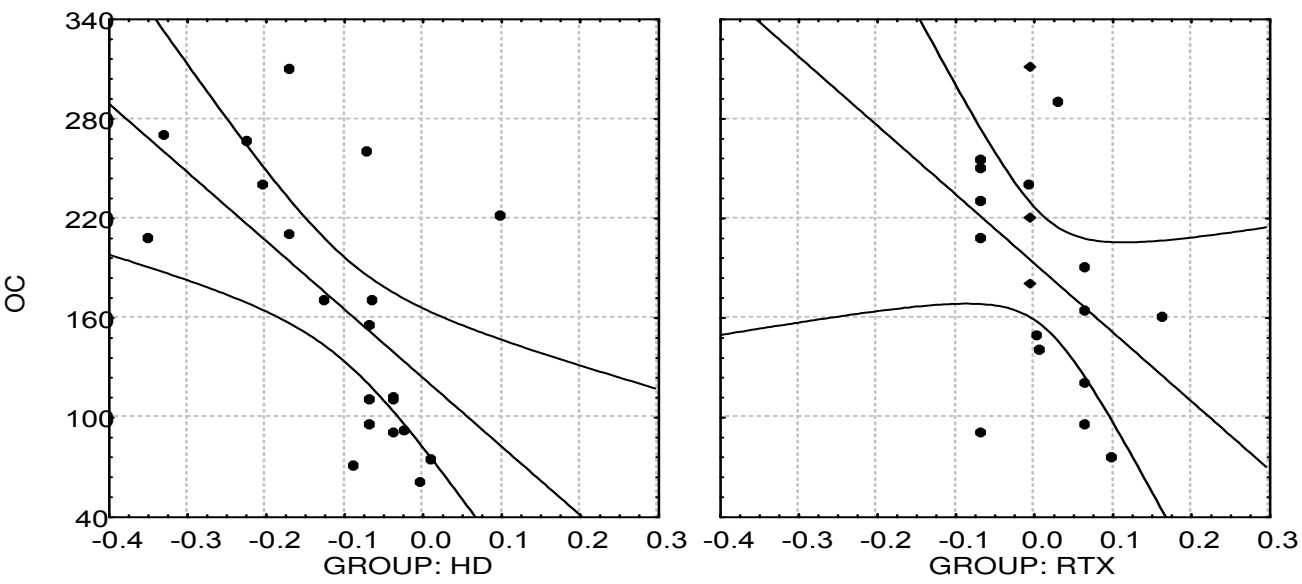

Annual T-score change at femoral neck

Fig. 3: Correlation between annual T-score change and serum OC
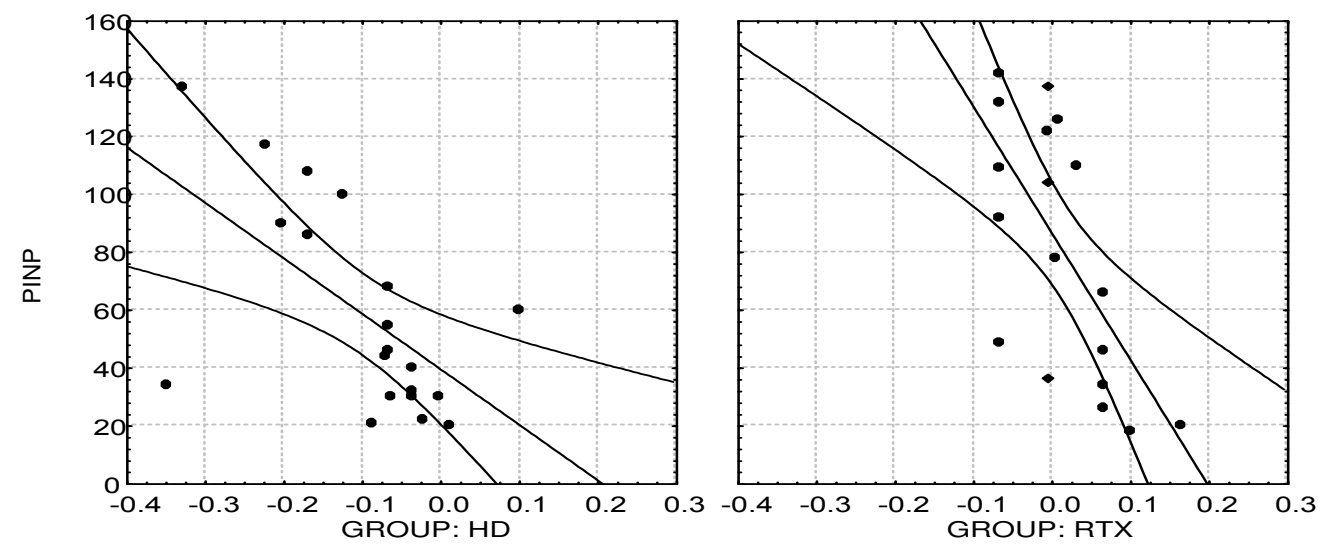

Annual T-score change at femoral neck

Fig. 4: Correlation between annual T-score change and serum PINP 


\section{Bone mineral density and markers}

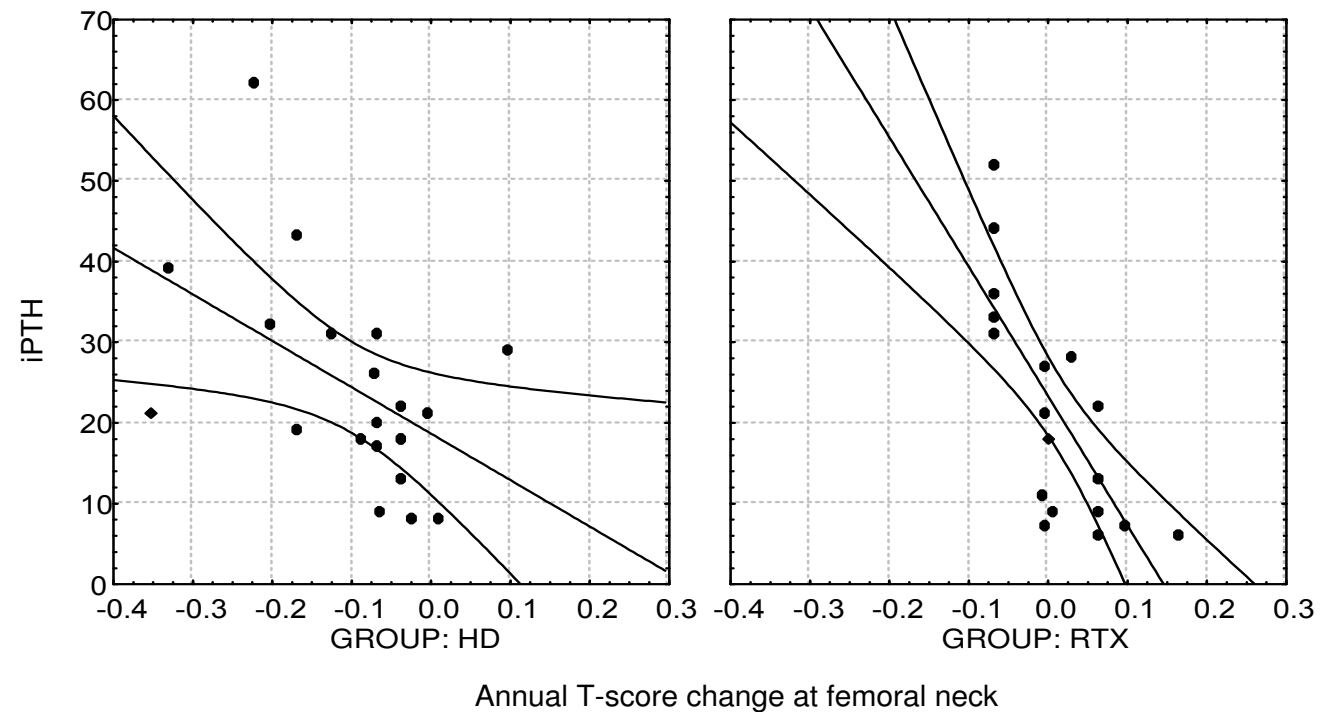

Fig. 5: Correlation between annual T-score change and serum iPTH

\section{Discussion:}

Several studies had shown a high prevalence of osteopenia and osteop orosis among patients receiving HD $2,3,12$. Although kidney transplan -tation represents the only treatment modality to replace endocrine and exocrine function in ESRD, the restitution of bone remodeling homeostasis after RTx is known to be incomplete ${ }^{13}$. Impaired recovery from renal osteodystrophy, persistence of secondary hyperparathy roidism and administration of immu nosuppressive medications, all may contribute to the development of post transplantation bone disease ${ }^{14}$. The first 6 to 18 months are thought to have the greatest impact on bone loss. Rates of bone loss approaching $6 \%$ to $9 \%$ in the lumbar spine BMD during the first 6 months after transplantation had been reported ${ }^{15}$. The issue whether or not this dramatic decline in BMD is permanent and progressive is currently unresolved. Only limited and inhomogeneous data are available on the long-term development of BMD in the renal transplant populations ${ }^{16,17}$.
To the best of our knowledge, this is one of few studies addressing metabolic bone changes by markers of bone turnover and DEXA over 3 years. Furthermore, in our trial we investigated possible differences in bone markers behaviour between the two population on replacement therapy; patients on HD and patients with renal transplantation.

Causes of ESRD in the HDgroup and RTx-group were essentially the same. Causes included diabetic nephropathy $(18.42 \%)$, obstructive uropathy and chronic pyelonephritis $(13.16 \%)$, polycystic kidney disease $(7.89 \%)$, hypertensive nephropathy $(5.26 \%)$ and chronic glomerulonephritis $(5.26 \%)$ for the two groups collectively. Comparison of the distribution of the etiological factors in the two groups were statistically non significant (table 1). These results are contradictory to those reported by de Sévaux et al. (1997) who reported glomerulonephritis as the most common cause of ESRD in their study ${ }^{18}$. However, our results match those reported by Jamal et al. 
(2002), who reported diabetic nephropathy as the most common cause of ESRD among their patients ${ }^{3}$.

In both groups, markers of calcium homeostasis including serum calcium, phosphorus, ALP and calcitriol, were within acceptable values. These data parallel those reported by Carlini et al. (2000) $)^{2}$, Barnas et al. $(2001)^{19}$, and de Sevaux et al. $(2002)^{14}$. Although serum calcium $(8.8 \pm 0.9 \mathrm{mg} / \mathrm{dL})$ and calcitriol $(22.7 \pm$ $4.9 \mathrm{ug} / \mathrm{L}) \quad$ were higher, while phosphorus $(3.8 \pm 1.4 \mathrm{mg} / \mathrm{dL})$ and ALP $(94.4 \pm 8.8 \mathrm{IU} / \mathrm{L})$ were lower in RTxgroup compared to HD-group $(8.5 \pm 1.4$ $\mathrm{mg} / \mathrm{dL}$ for calcium, $19.8 \pm 5.6 \mathrm{ug} / \mathrm{L}$ for calcitriol, $4.3 \pm 1.1 \mathrm{mg} / \mathrm{dL}$ for phosphorous and $108.3 \pm 13.5 \mathrm{IU} / \mathrm{L}$ for ALP), yet this difference was statistically non significant (table 2 ).

When markers of bone formation in the HD-group (27.65 \pm 9.95 IU/L, $164.6 \pm 78.33 \mathrm{ug} / \mathrm{L}$, and 58.5 $\pm 35.75 \mathrm{ug} / \mathrm{L}$ for BAP, OC, and PINP, respectively) were compared to the RTx-group $(32.17 \pm 9.76 \mathrm{IU} / \mathrm{L}, 187.11$ $\pm 68.68 \mathrm{ug} / \mathrm{L}$, and $80.39 \pm 43.97 \mathrm{ug} / \mathrm{L}$ for BAP, OC, and PINP, respectively), the difference was statistically non significant. However, values for these markers were numerically higher in the RTx-group, probably representing higher rate of bone formation in this group. Also, markers of bone resorption (PYL and DPYL) showed nonsignificant difference between both groups (table 3). All markers were above the reference values, perhaps signifying a state of increased bone resorption and relative secondary increased bone formation ${ }^{20}$ in both groups. Coupled with the results of decreased BMD in this study, it was implied that serum levels of bone formation markers in these patients represent the sum of the increase resulting from increased bone resorption and the relative decrease secondary to impairment of bone formation ${ }^{21}$.

Also, iPTH was higher in both groups compared to the reference values. Mean value $( \pm \mathrm{SD})$ for $\mathrm{iPTH}$ in the HD-group $(24.35 \pm 13.09 \mathrm{pmol} / \mathrm{L})$ was numerically higher compared to the RTx-group $(21.11 \pm 14.03 \mathrm{pmol} / \mathrm{L})$, however this difference was statistically non significant (table 3). Similar results had been reported by Dumoulin et al. $(1997)^{22}$ and Salem $(1997)^{23}$. This increase in both groups, especially in HD-group, likely reflects persistence of secondary hyperparathyroidism from the predialysis uremic state ${ }^{2}$.

In this study, BMD had been assessed by DEXA. DEXA is recommended and FDA-approved for BMD assessment; it is precise, non invasive, has low radiation, and takes 10 minutes to administer ${ }^{24}$. Because annual losses of bone mass normally averages $1 \%$ / year, and the precision error of the current DEXA instruments approximately $1 \%$, follow up of BMD at intervals shorter than 2 years cannot provide reliable information ${ }^{24}$. DEXA was repeated in our study after 3 years.

$\mathrm{T}$-scores (SD difference from the adult reference BMD) at both femoral neck and lumbar spines were low at inclusion time $(-1.89 \pm 0.95$ and $-2.21 \pm 0.93$, respectively for HD-group and $-1.69 \pm 1.2$ and $-1.91 \pm 1.02$, respectively for RTx-group). Numbers of patients categorized by WHO criteria 24 as having osteopenia (T-score $<-1$ to $-2.5)$ at either site were $40.0 \%$ and $38.89 \%$ for the HD-group and RTxgroup, respectively. While those qualified a diagnosis of osteoporosis (Tscore $<-2.5$ ) were $45.0 \%$ and $33.33 \%$ for the HD-group and RTx-group, respectively. Only $15.0 \%$ and $27.78 \%$ for the HD-group and RTx-group, respectively, had normal T-score ( $\mathrm{T}$ score $>-1$ ) for both femoral neck and 
lumbar spines at inclusion (fig. 1). These results are close to those published by Gabay et al. $(1993)^{25}$, and Jamal et al. (2002) $)^{3}$. It has been suggested that the accelerated loss of bone mineral density during the initial post transplantation years could be caused by the effect of high doses of glucocorticoids during this period ${ }^{26}$. Glucocorticoids may act by increasing osteoclastic resorption and decreasing osteoblastic activity and bone minerali zation. It may also affect osteoblast function through indirect mechanisms, including decreased intes -tinal calcium absorption and modulating of cell response to PTH and calcitriol, as well as cytokine production ${ }^{2}$.

Comparing T-scores between both groups at both sites at inclusion and 3 years later was statistically non significant (table 4). However, comp arison between $\mathrm{T}$-score at inclusion and 3 years later for the HD-group showed a significant drop of BMD at both femoral neck (from $-1.89 \pm 0.95$ to $2.19 \pm 0.90, \quad \mathrm{P}<0.001)$ and lumbar spines (from $-2.21 \pm 0.93$ to $-2.37 \pm$ $0.92, \mathrm{P}<0.001)$, reflecting a state of continued bone resorption / relative decrease in bone formation. On the other hand the mean change for $\mathrm{T}$ scores at $1^{\text {st }}$ and $2^{\text {nd }}$ DEXA for RTxgroup was statistically non significant for both femoral neck (from $-1.69 \pm$ 1.20 to $-1.66 \pm 1.14$ ) and lumbar spines (from $-1.91 \pm 1.02$ to $-1.89 \pm 0.89$ ), reflecting a state of stabilized bone resorption / relative increase in bone formation (table 5).

A significant annual drop of $\mathrm{T}$ score was recorded at both femoral neck $(\mathrm{P}<0.05)$ and lumbar spines $(\mathrm{P}<0.001)$ for the HD-group compared to the RTXgroup. This difference of annual T-score change in favour of RTx-group could be attributed to improved bone metabolism secondary to regained endocrine renal function (table 4).

Correlating BMD changes to markers of bone turnover (table 6,7 and fig. 2-5), only PINP showed consistent (in both groups) significant negative correlation at the femoral neck $(\mathrm{r}=-0.6$ and -0.66 for HD-group and RTx-group, respectively). Other markers, although showed a significant negative correla tion with T-score of one group, they failed to maintain this significance in the other group. Furthermore, PINP was the only marker that showed consistent significant positive correlation with iPTH ( $\mathrm{r}=0.81$ and 0.60 for HD-group and RTx-group, respectively), which is a momentous predictor of bone turnover 27. Also, it showed significant positive correlation with both markers of bone formation and markers of bone resorption (table 6 and table 7). Given the report of being the least affected by HD (compared to BAP and OC), and having a specific-receptor clearance in the liver (rather than kidney compared to BAP and OC) ${ }^{28}$, PINP attest to be the best marker that could relate with metabolic bone changes in these patient subsets.

\section{Conclusion And Recommendations:}

Irrespective of normal calcium homeostasis parameters, low BMD is a prevalent disorder among patients on regular HD and renal transplants. Follow up for 3 years showed stabilization of BMD for those patients with renal transplants, contrary to continued bone loss in patients on regular HD. This could raise recomm endation for calcium and calcitriol supplementation, especially in the predialysis period, early post transplantation period, and continued guided replacement for those on maintenance HD. Serum PINP showed 
best correlations with BMD changes and $\mathrm{PPTH}$ and could be considered a reliable marker reflecting bone formation in those patients.

\section{References}

1. Haas M, Leko-Mohr Z, Roschger $\mathrm{P}$, et al: Osteoprotegerin and parathyroid hormone as markers of high-turnover osteodystrophy and decreased bone mineralization in hemodialysis patients. Am J Kid Dis 39(3):580-6, 2002.

2. Carlini RG, Rojas E, Weisinger JR, et al: Bone Disease in Patients With Long-Term Renal Transplantation and Normal Renal Function. Am J Kid Dis 36(1):1606, 2000.

3. Jamal SA, Chase C, Ingrid GY, et al: Bone density and heel ultrasound testing do not identify patients with dialysis-dependent renal failure who have had fractures Am J Kid Dis 39(4):843-9, 2002.

4. Ishimura E, Okuno S, Kim M, et al: Increasing body fat mass in the first year of hemodialysis. J Am Soc Nephrol 12:1921-1926, 2001.

5. Inaba $M$, Nishizawa $Y$, Mita $K$, et al: Poor glycemic control impairs the response of biochemical param eters of bone formation and resorption to exogenous 1,25dihydroxyvitamin $\mathrm{D}_{3}$ in patients with type 2 diabetes. Osteoporos Int 9:525-531, 1999.

6. Gomes B Jr, Ardakani S, Ju J, et al: Monoclonal antibody assay for measuring bone-specific alkaline phosphatase activity in serum. Clin Chem 41:1560-1566, 1995.

7. Furumitsu Y, Inaba M, Yukioka $\mathrm{K}$, et al: Levels of serum and synovial fluid pyridinium crossl inks in patients with rheumatoid arthritis. J Rheumatol 27:64-70, 2000.
8. Tahtela R, Turpeinen M, Sorva R, Karonen S-L: The aminoterminal propeptide of type I procollagen: Evaluation of a commercial radioi mmunoassay kit and values in healthy subjects. Clin Biochem 30:35-40, 1997.

9. Woitge HW and Seibel MJ: Biochemical Markers to Survey Bone Turnover. Rheum Dis Clin North Am. 27(1):49-80, 2001.

10. Lepage R, Roy L, Brossard JH, et al: A non-(1-84) circulating parath yroid hormone (PTH) fragment interferes significantly with intact PTH commercial assay measure ments in uremic samples. Clin Chem 44:805-809, 1998.

11. Jergas M, Breitenseher M, Gluer $\mathrm{CC}$, et al: Which vertebrae should be assessed using lateral dual energy X-ray absorptiometry of the lumbar spine. Osteoporos Int 5:196-204, 1995.

12. Taal MW, Masud T, Green D, Cassidy MJ: Risk factors for reduced bone density in haemod ialysis patients. Nephrol Dial Transplant 14:1922-1928, 1999.

13. Monier-Faugere MC, Mawad H, Qi Q, et al: High prevalence of low bone turnover and occurrence of osteomalacia after kidney transplant -tation. J Am Soc Nephrol 11:10931099, 2000.

14. de Sévaux RG, Hoitsma AJ, Corstens FHM, Wetzels JFM: Treatment with Vitamin D and Calcium Reduces Bone Loss after Renal Transplantation: A Randomized Study. J Am Soc Nephrol 13(6):1608-14, 2002.

15. Bagni B, Gilli P, Cavallini A, et al: Continuing loss of vertebral mineral density in renal transplant recipients. Eur J Nucl Med 21:108112, 1994. 
16. Pichette V, Bonnardeaux A, Prudhomme L, et al: Long-term bone loss in kidney transplant recipients: A cross-sectional and longitudinal study. Am J Kidney Dis 28:105-114, 1996.

17. Cayco AV, Wysolmerski J, Simpson C, et al: Posttransplant bone disease: Evidence for a high bone resorption state. Transplantation70:1722-1728, 2000.

18. de Sévaux RG, Hoitsma AJ, van Hoof HJ, et al: Vitamin D metab olism and bone mineral density after kidney transplantation. J Am Soc Nephrol 8: 550, 1997.

19. Barnas U, Schmidt A, Seidl G, et al: A Comparison of Quantitative Computed Tomography and Dual X-Ray Absorptiometry for Evaluation of Bone Mineral Density in Patients on Chronic Hemodialysis. Am J Kid Dis 37(6):1247-52, 2001.

20. Urena P, De Vernejoul MC: Circulating biochemical markers of bone remodeling in uremic patients. Kidney Int 55:2141-2156, 1999.

21. Wagner MS, Stracke S, Jehle PM, et al: Evaluation of IGF system component levels and mitogenic activity of uremic serum on normal human osteoblasts. Nephron 84:158166,2000

22. Dumoulin G, Hory B, Nguyen NU, et al: No trend toward a spontaneous improvement of hyperparathyroidism and high bone turnover in normocalcemic longterm renal transplant recipients. Am J Kidney Dis 29:746-753, 1997.

23. Salem MM: Hyperparathyroidism in the hemodialysis population: A survey of 612 patients. Am J Kidney Dis 29:862-865, 1997.

24. National Osteoporosis Foundation. Osteoporosis: review of the evid ence for prevention, diagnosis, and treatment and cost-effective analy sis. Introduction Washington, DC: National Osteoprosis Foundation Osteop -orosis Int Suppl; 1998. p. S7-S80.

25. Gabay C, Ruedin P, Slosman D, et al: Bone mineral density in patients with end-stage renal failure. Am J Nephrol 13:115-123, 1993.

26. Dissanayake IR, Epstein S: The fate of bone after renal transplantation. Curr Opin Nephrol Hypertens 7:389-395, 1998.

27. Qi Q, Monier-Faugere MC, Geng $\mathrm{Z}$, Malluche HH: Predictive value of serum parathyroid hormone levels for bone turnover in patients on chronic maintenance dialysis. Am J Kidney Dis 26: 622-631, 1995.

28. Jensen PB, Rasmussen HB, Pedersen FB: Serum concentration of the aminopropeptide of type I procollagen in patients on haemoand peritoneal dialysis. APMIS 105:371-377, 1997. 


\title{
قياس كثافة العظام و قياس معاملات العظام في مرضى الفشل الكلوى و الذين اجروا عمليات غرس الكلى
}

\author{
سمير معوض ابراهيم"، خالد عبد الجيد*، مجدى الشرقاوى*، عبد الز اهر خطاب** \\ *مدرس أمر اض باطنة طب عين شمس ** مدرس علم الباثولوجى طب الزقازيق
}

مقدمة: يعتبر نقص الكثافة العظمية من أمضاعفات المعروفة لمرضى الغسيل الكلوي و زرع الكلي . خصو صا على المدى الطويل.

المرضى وطرق البحث:تمت هذا البحث دراسة بحموعتين من المرضى: البحموعة الأولى شملت 20 مريض معاشون

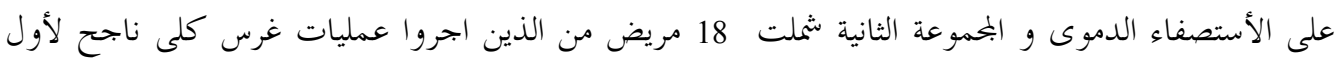

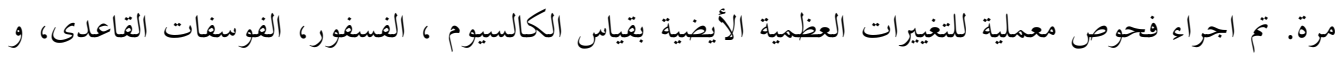

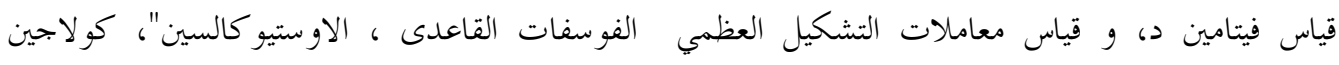

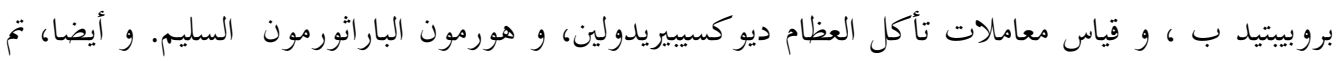

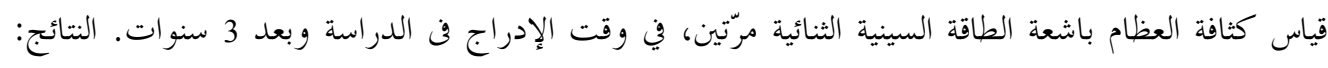

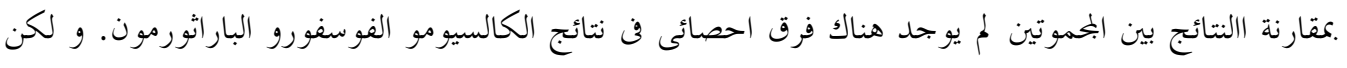

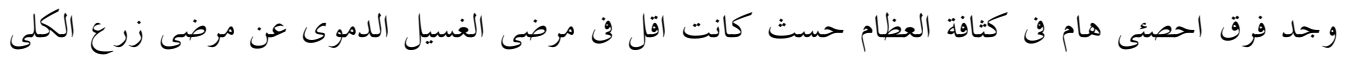

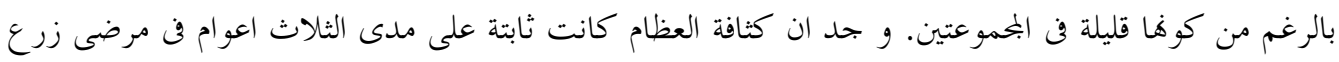

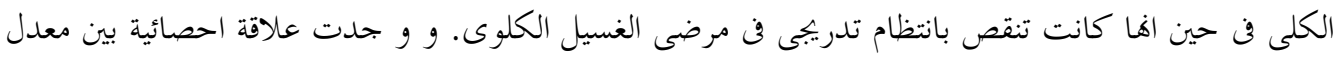

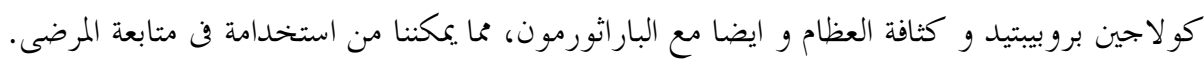

